\title{
The Islamic Perceptions of Knowledge vis-à-vis the Western Perceptions as the Bedrocks of Educational Systems
}

\author{
Muhammad Tahir Saleem \\ Ph.D Scholar, Department of Islamic Studies, National University of Modern Languages (NUML), Islamabad, \\ Pakistan
}

\begin{abstract}
Knowledge and its various perceptions from the ancient times to the Islamic and the modern era constitute essentials bedrock of Islamic and Western system of education. Knowledge in the Islamic world finds its basis in the Qur'ān as well as the in the Muslim philosophies of education, while the Western education is based on the Western philosophies besides the physiological educational concepts which developed in the $20^{\text {th }}$ century. Both philosophies, Islamic and Western, have led to the development of two distinct systems of education currently prevalent in the Muslim world, particularly in Pakistan. The inadequacy of the Islamic system of education to meet the challenges of today has been long felt. This paper attempts to investigate into this broad field of inquiry in the hope that its serves to understand the educational superstructures raised on two philosophies of education. Further, it highlights how the Islamic systems initiated the spread of education initially and yet with time it lost its appeal. It has been shown how the later philosophies of education in the West have dominated the world and today's educational scenario with the lesson that the Muslim world should heed to the demands of the modern times and improve their systems of education.
\end{abstract}

Keywords - Knowledge and its perceptions, the Islamic philosophy of education, the Western philosophy of education, Educational concepts of knowledge, the Islamic vis-à-vis western system of education.

\section{Introduction}

Knowledge and its perceptions help raise on them appropriate educational systems in the world. It is the education of a nation which in today's scenario matters in the supremacy among the global powers. There is a lot of information available on knowledge, and yet it is so scattered that a holistic view of the various perceptions of knowledge is not easily available. So much so that even confusion prevails about the definition of knowledge in the Islamic world today [1]. Therefore, various perceptions of knowledge from ancient to the modern time have been discussed as well as the systems of education built on them so as to serve as the guiding principles for any discussion on education. The paper discusses the subject under the heads: the Islamic perception of knowledge, the ancient philosophies of education, the Muslim philosophies of education, the Western philosophy and the educational concepts, the two systems i.e. Islamic and Western, of education.

\subsection{Definition of Knowledge}

\section{The Islamic perception of knowledge}

Knowledge is defined as the perception of the nature of things: the perception of a thing as its is [2]. Etymologically [3] the word 'ilm (knowledge) has its roots in ayn, läm, mìm with its basic meanings of 'alāmah, meaning the 'way sign'. According to Rāghil al-Isfahāni [4], al- 'alm is 'the trace (or mark) by which something is known (al-athar alladhi yu'lam bihi al-shay). Rosenthal [5] has further made it more explicit:

... the meaning of 'to know' is an extension, peculiar to Arabic, of an original concrete term, namely, 'way sign.' . . . the connection between 'way sign' and 'knowledge' is particularly close and takes on especial significance in the Arabian environment. For the Bedouin, the knowledge of way signs, the characteristic marks in the desert which guided him on his travels and in the execution of his daily tasks, was the most important and immediate knowledge to be acquired. In fact, it was the kind of knowledge on which his life and wellbeing principally depended. Thus, it is easy to see how in a largely nomadic environment, the general concept of knowledge was able to develop from the concrete process of being acquainted with 'way sings'.

\subsection{The Qur'ānic concept}

The Qur'ann underlines the importance of knowledge in the following verse: Say: 'are they equal those who know and those who know not? Only men of understanding (possessed of mind) remember (receive admonition) (39:9). 'Those who know and those who not' implies scholars of knowledge and the ignorant 
respectively [6]; and only those who practice in accordance with the dictates of knowledge are the ones who benefit from knowledge.

The Qur'ān further states: Nūn! By the Pen, and that what they write. (68:1). Knowledge, expressed through pen, is the distinctive feature of the developed human species. Mankind, from antiquity to the present time, has endeavored to acquire knowledge in order to meet his requirements of food, shelter and daily comforts, besides understanding the natural phenomena. However, an indirect purpose has been to gain supremacy over his rivals. In fact, the entire history of mankind is the history of development of knowledge. It is witnessed today in the global sway of superpower(s) equipped with the latest scientific knowledge and technology vis-à-vis the developing countries which lag far behind in the pursuit of knowledge, which is driven by as set of complex factors, of which education is a vitally important component. Further, to clarify the Qur'ānic concept, it is pointed out that knowledge is the antonym of both ignorance and mere conjecture as made explicit by the Qur'ān in the following two verses: Repentance with Allah is only for those who do evil in ignorance (4:17). They have no knowledge about it, but only follow a conjecture (surmise) (4:157). There are 24 verses in the Qur'ān pertaining to 'ignorance', and 69 verses related to 'conjecture'.

The importance of knowledge in Islam is borne by the fact that holy Prophet supplicated for 'the knowledge of ultimate nature of things' [7]: Thus, the holy Prophet's prayer, taught by the Creator, emphasized the acquiring of knowledge: And say, 'Oh my Lord! Increase me in knowledge. (20:114). Education and wisdom are two terms related to knowledge and require explanation:

- Knowledge vs Education Knowledge gained through formal process of schooling is education. Thus, knowledge is a general term conveying informally acquired information through senses and thoughtprocesses besides life experiences. Knowledge is limitless, such as spiritual and secular kinds of knowledge, while education is relative, such as primary and higher education, arts and scientific education, etc. Knowledge is an open field while education has defined curriculum, and is obtained through educational institutions. Thus, knowledge and education are intertwined and intimately related; the difference between them is only subtle.

- Knowledge vs Wisdom Wisdom is another term related to the Qur'ānic knowledge. 'Knowledge can be steadily increased and learning advanced but we do not . . grow in wisdom'. We do not ordinarily think a man wise unless he acts wisely; that is why 'wordily wisdom', being a counterfeit of wisdom, is condemned; thus, wisdom seems to combine knowledge and action. 'Wisdom entereth not into a malicious mind, and that knowledge without conscience is but the ruin of the soul', wrote Gargantua to his son while the latter was a student in Paris, admonishing him in the words of Solomon. Socrates refused to call any man wise, 'for that is great name which belongs to God alone', for men, 'lovers of wisdom' or 'philosophers' are the modest and befitting titles' [8]. Further discussion follows in 4.3.2 under al-Hikmah.

\section{a. The Indian philosophy}

\section{The Ancient Philosophies of Education}

The Hindu philosophy recognizes two sources of knowledge: 1) Sruti: Perception, and 2) Smrti: Inference. The realm of one is amenable to reason, while of the other (Brahman) is beyond the reach of reason. The Indian philosophy is rooted in Vedas and Bhagavad Gita:

- Vedas, an anthology of transcendental philosophy of man's such for infinite bliss developed from 1500600 BC [9], which contain hymns concerned with worship of gods: the personification of natural forces; $R g$-Veda being the oldest and Upanishads, antedate the birth of Buddha in the fifth century BC, the concluding portion of the Vedas: 'A man has to renounce all activity for worldly goods if he wants to achieve spiritual unity with the Supreme Being' [10,9].

- Bhagavad-Gita, written in the $2^{\text {nd }}$ century BC during the epic period, is the epitome of the whole Vedic teachings and basic to Hindu religious belief [9]. Further, the Hindu philosophy has been influenced by Jainism (of pessimism), and Buddhism of (self-discipline through renunciation).

\section{b. The Chinese philosophy}

The Chinese philosophy of knowledge stems from 'practical reason' against the Hindu 'speculative reason'. The Chinese being mainly agricultural people, their philosophy centered on the utilization of land. Thus, they follow and admire nature, and 'desire no change, nor can they conceive of any change'. There followed two streams of the Chinese philosophy: 
- Confucianism, founded by Confucius (551-479 BC), stressed moral principles [11] in family obligations while Taoism emphasized 'power, beauty and mystery of nature' and Mohism, founded by Mo Tzu (c. 479-438 BC), stressed 'an all-embracing love based upon utility' [12].

- Buddhism, founded by Guatma Buddah (c. 563-483 BC), almost a contemporaneous thought prevailed in south-east Asia (India, China, Sri Lanka, Japan, Thailand, etc.) from almost $5^{\text {th }}$ century BC to the modern times. The Surangama Sutra, written in Sanskrit about the $1^{\text {st }}$ century AD, presents the meaning of ultimate reality as taught by Buddah [9].

\section{c. The Iranian philosophy}

The Iranian philosophy of knowledge has its roots in the teachings of Zarathustra or Zaratust / Zartus, or in Greek Zoroaster [13] who lived in the mid-late second millennium BC. He was a religious reformer - who created a new monotheism - the veneration for a single supreme God, Ahura Mazdāh, the 'Wise Lord', who was 'perfect, eternal, unchangeable, the Creator of the heaven, the shaper of the universe. When manifested, he is known in his two aspects - one is permanent, constructive, light, life and good; the other transitory, destructive, dark, death and evil. . . Matter is a receptacle of these two aspects' [14].

The Zorastrian religion believes in a dualistic world view: good and evil [15]. The Iranians' philosophy is old and has influenced the definitions and trends of knowledge, particularly in Iran. Knowledge, thus, becomes an abstract quality. However, later Iranian philosophers made several views on knowledge, discussed under Muslim philosophers.

\section{d. The Greek philosophy}

The Greek philosophy and Greeks knowledge has dominated down to the recent times. The earlier Greek philosophy was more based on imagination, rather than reason, and its language was poetry [16]. The Greeks produced great scholars Socrates (469-399 BC), Plato (427-347 BC) and Aristotle (384-322 BC). Plato stands out among them and his Republic[9] among other things discussed the educational philosophy. He believed that education begins with childhood and lasts till the end of life. He envisaged giving to the body and the soul all the perfection, besides preparing the individual for the welfare of the society. Plato's philosophy has dominated the western education for centuries. Plato, however, did not believe in perception for obtaining knowledge. He is well known for his famous simile of the cave or den [17].

Aristotle, best known as teacher of Alexander - Alexander the Great - studied at Plato's academy at Athens and laid the foundations of study of sciences. He established Lyceum - an educational institution - based on Aristotle's habit of walking while teaching, the walking school called Peripatetic school. His aim of education was the attainment of happiness through virtue. Aristotle used both inductive and deductive methods of seeking knowledge. He was the first to have initiated studies on modern subjects, such as physics, metaphysics, mechanics and physiology. Like Plato, he thought education was the responsibility of the state. Aristotle knowledge was transmitted to Europe through Arabic versions of Aristotle's works.

\section{The Muslim Philosophy of Education}

Muslim philosophers contributed significantly towards the development of knowledge. There are great names of Muslim philosophers such as al-Kindi (260/873) - the Philosopher of the Arabs, who brought accord between religion and philosophy and paved the way for al-Färābi (339/950), Ibn Sinna (428/1037) - called in the West Avicenna, and Ibn Rushd (595/1198), known in the West as Averroes. However, it was al-Ghazāli (505/1111) and Ibne Khaldun (809/1406) who are more prominent for educational philosophy. There are two main theories of knowledge:

- Mu'tazlites' theory of knowledge (from the word i'tizal which means to withdraw or secede; its founder was Wasil ibn 'Ata (131/748). Mu'tazlites believed reason t be with the arbiter of truth) recognizes knowledge belonging to two branches: 1) parasensory: beyond the physical phenomenon, and 2) sensory.

Physical knowledge according to Mu'tazlites is acquired through five physical senses (sense-perception). This represents the first stage, while the faculty of reason (' $a l$-' $a q l$ ) is considered important for, what they call, rational knowledge [18].

- Ash'arites theory of knowledge (Ash'arites emerged during the $4^{\text {th }} / 10^{\text {th }}$ and $5^{\text {th }} / 11^{\text {th }}$ centuries to purge Islam of all non-Islamic elements and laid the foundation of an orthodox Islamic theology opposed to the rationalistic Kalām of the Mu'tazlites) was is reaction to the Mu'tazlites' emphasis on reason and comprises three degrees: 1) sense-perceptions, 2) scientific knowledge (to the established by rational proofs), and 3) mystic knowledge which ultimately ends in a vision of the ultimate truth. Iqbal criticizes the Ash 'arites approach for being ignoring the mental activity [18].

Some of the Muslim philosophers, important for their educational concepts, are briefly discussed below:

- Al-Kindi's (260/871) believed into two sources of knowledge: by the senses or acquired by the reason. The senses apprehend the material form and reason conceives the universal - the spiritual form. 
- Ikhwan al-Safa (373/983) - It was a group of philosopher, originated in Basrah, which worked to farm of kind of ethico - spiritual community among Muslim against the prevailing diversity of religious sets [16] believed that man at the time of his birth does not possess any knowledge except the potentially endowed knowledge which man develops later through the use of his faculties and efforts. However, knowledge of one's self is the surest and the most deserving of preference. It is the righteous conduct which lifts the soul to the highest level of knowledge [18].

- Al-Mäturīdi (333/944), in his Kitāb al-Tauhīd gives three means of acquiring knowledge: 1) Sense-organs

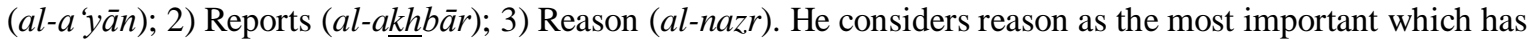
been greatly stressed by the Qur'ān [16].

- Al-Fārābi (339/950), called 'The Second Teacher' followed the footsteps of Aristotle and favoured science and advocated experimentation. Al-Fārābī agrees with Plato in the system of education and learning from childhood and believed that speculative sciences are learnt by the elite. In brief, Al-Fārābī considers while sensations and perceptions or the primary sources of knowledge but they are subject to the final scrutiny by $\operatorname{logic}[19,20]$.

- Maskawaih (421/1030), in follower of al-Fārābī believed that all knowledge starts from sensations transforming gradually into perception. The earlier sensations are conditioned by an external physical world acting as a stimulus. But the ultimate progress of knowledge lies in that man should be able to think without being conditioned by matter [18].

- Ibn Sina (428/1037), having influenced the West profoundly, and Kitāb al-Shifā his famous treatise, elaborated his doctrine of intellect, originally given by Aristotle obscurely. His doctrine distinguishes between a potential intellect in man and active intellect outside man, through the influence and guidance of which the former develops and matures [21].

- Al-Ghazāli (505/1111) - the famous theologian, jurist and süfi -challenged the philosophy of Aristotle and its Muslim followers, al-Fārābi and ibn Sīna. His philosophy of education is pragmatist - emphasizing both the spiritual and materialistic developments. Nizam al-Mulk appointed him to the chair of theology in the Nizamiyyah Academy at Nīshapūr Baghdad in 484/1091. He remarked, 'Plato is dear to us, and truth is dear, too. Nay, truth is dear than Plato' [22, 23].

- Al-Mas'udi, Abu al-Hassan (345/956), Al-Biruni, Abu Raihan (440/1048) and Al-Idrisi (561/1166) need mention for their pioneering knowledge of primarily history and geography and their contributions to the development of knowledge.

- Qutb al-Din al-Shìrāzi (710/1311) discusses knowledge from a philosophic point of view and is hardly relevant for today's situation. He divides knowledge into two: 1) The philosophical (al-hikmī) - further divided into theoretical and practical philosophy, and 2) the non-philosophical (ghayr al-hikmī), divided into religious and the non-religious [24].

- Ibn Khaldūn (809/1406) - The first sociologist and philosopher of history, the author of famous Muqaddimah. His concept of 'aşabiyyah (social solidarity) is said to be governing the rise and fall of groups, institutions and nations. He considered education to embrace both the intellectual and moral training and the system of education should be based on the ideals of society [23, 25].

- Shihāb al-Din Suhrawardi (632/1234), distinguishes knowledge as: a legacy ('ilmal-wirāthah) from the prophets and knowledge gained formal education ('ilm al-dirāsah). The latter is of three stages: 1) knowledge by inference, 2) knowledge by perception (or observation), and 3) knowledge by personal experience or intuition ('ilm al-yaqīn, 'ain al-yaqīn, and haqq al-yaqīn) [16].

- Al-Jili - Abd al-Karīm b. Ibrāhīm al-Jīli (832/1428) was a mystic and according to him the first form of knowledge is instinctive or what he calls inspirational ( 'ilm-I ilhämi), possessed even by animals. The other inferential knowledge possessed by man, angels, and jinn [26].

- Mulla Şadra - Şadr al-Dīn Shīrazi (1050/1640) influenced the intellectual life of Persia during the past three centuries and a half. He rekindled the intellectual thought in the Muslim world after the Mongol invasion. According to Mulla Şadra, there are two forms of knowledge: that derived from formal instruction $(\mathrm{al}$ - $\mathrm{ilm}$ al-şuwari) and that which comes from intellectual intuition (al-'ilm al-ladunni). The former is acquired in school while the latter is derived through the purification of the soul and the catharsis (tajrid) of the intellect. Also he divides knowledge ('ilm) into acquired (huşüli) knowledge and innate (hudüri) knowledge [27].

- Ibn Hazm (456/1063) believed that we perceive objects by five senses and reason; the sixth sense is the soul's knowledge of primary things. He thought that knowledge arises from: 1) Sensory perception (shahädat al-hawās), that is, observation or sensory evidence. 2) Primary reason (badīhat al-'aql or awwal $a l$ - $a q l$ ), that is, a priori reason without the use of the five senses and 3) Proof (burhān), which goes back, either closely or remotely, to the evidence of the senses or to primary reason [16].

- Muhammad Iqbal (1357/1938) - poet philosopher - has expressed his views in his Reconstruction of Religious Thought in Islam. He says 'There was a time when European thought received inspiration from the 
world of Islam' and yet Islamic thought had been stagnant during the last 500 years, and 'the main purpose of the Qur'ān is to awaken in man the higher consciousness of his manifold relation with God and the universe. In order to secure 'a complete vision of Reality, therefore, sense-perception must be supplemented by the perception of what the Qur'ann describes as Fuād or Qalb, i.e. heart' (mind). He thinks: 'the only course open to us is to approach modern knowledge with a respectful but independent attitude and to appreciate the teachings of Islam in the light of that knowledge [28].'

\section{The Western Philosophy and Educational Concepts}

The power of Church dominated the West from about $400 \mathrm{AD}$ to about $1400 \mathrm{AD}$ and the period from 600 to 1000 AD was the Dark Ages of Europe, when 'from India to Spain, the brilliant civilization of Islam flourished', and 'throughout the Middle Ages, the Mohammedans were more civilized and more humane than the Christians'. After the death of Augustine in 430, there was little philosophy in Europe; it was a century of destruction'; cleanliness was viewed with abhorrence; lice were called 'pearls of God', and were a mark of saintliness.

The first glow of science in Europe was the publication of Copernican theory in 1543 which, however, only became well known after it was improved by Kepler and Galileo in the $17^{\text {th }}$ century. Four great men: Copernicus (949/1543), Kepler (1039/1630), Galileo (1051/1642) and Newton (1139/1727) are the pre-eminent in the creation of science in Europe. European modern philosophy is marked by Descartes, Spinoza, Locke, Berkeley, Hume, Kant, Fichte, Hegel and Rousseau. It may be added that 'the works of Aristotle came to be for European philosophy what Bible was for theology - an almost infallible text' [29].

A brief discussion of the Western philosophers on concepts of knowledge follows [17]:

- Roger Bacon (693/1294), a mathematician at Oxford, is known for his views on the value of experimentation as a source of knowledge. Roger Bacon's books were condemned by the Church in 1278 and he was put in prison for 14 years. He was influenced by the Arabic writers - Avicenna, Averroes and al- Fārābī. He was the first amongst those who awakened Europe to knowledge [29].

- Francis Bacon (1035/1626) - who said 'knowledge is power' - was the founder of modern inductive method. He was hostile to Aristotle and his philosophy was practical: mastery over the forces of nature by scientific discoveries. However, he believed in both 'reason' and 'revelation' sources of knowledge [30]. 'The age of Bacon was one of the great progresses in natural sciences' [31].

- Thomas Hobbes (1090/1679) was an empiricist, like Locke, Berkeley, and Hume, but he unlike them, was an admirer of mathematical method. He was inspired by Galileo rather than Bacon [32].

- Rene Descartes (1049/-1650), a contemporary of Hobbes, endeavored to construct a philosophic edifice de novo. His cogito was the argument 'I think, therefore I am'. Thus he begins with skepticism with respect to senses [30].

- Spinoza (1087/1677) was concerned with religion and virtue. He thought there is only one substance, 'God or Nature'. He held freedom of opinion important. He thought that 'the highest good is the knowledge of God, and the mind's highest virtue is to know God'. Descartes admitted three substances: God, mind and matter while Spinoza admitted God alone. Thus, he only indirectly contributed to the concept of knowledge [9].

- John Locke (1115/1704), George Berkeley (1167/1753) and David Hume (1190/1776), belonged to the same era. Locke was influenced by Descartes and may be regarded as founder of empiricism: that all our knowledge is derived from experience. George Berkeley was heir of Locke and maintained that material objects only existed through being perceived: only minds and mental events can exists [9]. David Hume, another heir of Locke, further developed the empirical philosophy of Locke. His philosophy, according to Russell, represents the bankruptcy of $18^{\text {th }}$ century reasonableness. His skepticism rests upon his rejection of principle of induction [9].

- Immanuel Kant (1218/1804), the founder of German idealism, emphasized mind over matter. According to Russell, Kant, his immediate successors Fichte (1229/1814), and Hegel [17] (1246/1831) Schopenhauer (1276/1860) and Nietzsche (1318/1900), the former believed in the philosophy of, Kant, Plato, and the Upanishads while the latter is known for his philosophy of ethics - who believed in selfconsciousness to be the highest form of knowledge, tried to safeguard both knowledge and virtue from the subversive doctrines of the late $18^{\text {th }}$ century. His philosophy was an appeal to the heart against the cold dictates of theoretical reason [9].

\section{a. The educational philosophies}

Although the Western philosophers contributed the development of perceptions about knowledge, as briefly stated above. However, some of Western philosophers are particularly known for their contributions towards educational philosophy, such as the following [23]: 
- Jean Jacques Rousseau (1191/1778) represents the naturalistic movement of education: His novel Émile was the most significant book on education after Plato's Republic. 'Man is born free and everywhere he is chains'. He believed that education must accommodate itself to the child, and the child must not be accommodated to a pre-determined, adult-centred system of education. The first sentence of Emile, he published in 1762, reads 'Everything is good as it comes from the hands of the Author of Nature; but everything degenerates in the hands of man. Thus, Rousseau advocates the method of discovery of learning. This proved as a revolutionary publication on education in Europe, which however, the Church condemned and ordered to be burnt in Paris [32].

- Johann Heinrich Pestalozzi (1243/1827), a Swiss educational reformer, was asked by the Government to open a school for homeless orphans. There he introduced lessons in three 'R's,' together with industrial work and physical education, which included both play and drill. He viewed education as a means for social reforms. Pestalozzi owes much to Rousseau. But Pestalozzi is more human than Rousseau. His method of education awakens dormant capacities of the child and stimulates their development.

- Pestalozzi's contemporaries, two German philosophers: Friedrich Herbart (1257/1841) emphasized the connection between individual development and the resulting societal contribution, and Friedrich Froebel (1269/1852) a student of Pestalozzi, who laid the foundation for modern education based on the recognition that children have unique needs and capabilities. He developed the concept of the "kindergarten" schools.

- Friedrich August Froebel (1268/1852), a German educationist, whose miserable childhood led him develop and promote child education through play and art work in free atmosphere which he called kindergarten - a German word implying a children's garden - in which school is conceived as a garden, the teacher as the gardener and the students as tender plants.

- Maria Montessori (1372/1952), a German educator (an Italian physician) is known for her Montessori approach in educating children. The philosophy was developed in 1897 and the first school opened in 1907 in a rented building in Rome. The Montessori approach is characterized by emphasis on child's independence and his freedom, within the limits, in keeping with his psychological development and the technological advancement of the society. Students in this system learn through working with materials in a constructivist or discovery model rather than by direct instruction Montessori called this educational approach as 'scientific pedagogy'.

- John Dewey (1372/1952), an American pragmatist in education, is the last of the modern educationist who believed that knowledge was a means rather than end in itself. His philosophy is represented by experimentalism where students are taught to think. According to him, education is a continuous process of adjustment with the growth stages of life. He advocated freedom of thought and action [11].

\section{b. Educational concepts}

Attempts to such questions as: What should we teach? How students learn? The relation between the teacher and the taught?, etc. has led to six philosophical perspectives on education:

i. Essentialism refers to the 'traditional' or 'back to the basics' approach to education, grounded in conservative philosophy emphasizing on moral values and intellectual attainment of knowledge;

ii. Perennialism espouses the development of ever-lasting values (such as those of Plato, Aristotle and St. Thomas Aquinas) in education. Having some similarities with 'essentialism', Perennialism is not rooted in any particular time us place;

iii. Progressivism follows John Dewy in making education relevant to the needs of the time and to be harmonized with the environment;

iv. Existentialism follows the principle that 'Man is nothing else but what he makes of himself, existence precedes essence';

v. Reconstructionism is primarily progressivism except that it is critical of the contemporary society and attempt at transforming the existing culture and attempts at transforming the existing culture; and

vi. Critical pedagogy is a new version of 'reconstruction' and underscores the need to challenge the existing boundaries of knowledge and create new once.

Besides this it is important to keep the child psychology in view because it is only through understanding the development of the child that we can properly educate him according to this stage of his development [33]. However, the latest educational psychological trends include:

- Cognition (from Latin, cognoscere, to know) - A term applied for mental processes which are a function of the brain - is a faculty for the processing of information, applying knowledge and changing preferences. Cognitive processes can be natural or artificial. Since 1960s cognitivism has provided learning perspectives leading to theories of learning. Edward C. Tolman (1959) was one who proposed cognitive maps for rats and other organisms. 
- Gestalt psychology (German word Gestalt mean structured whole) emphasized importance of perception, learning, and problem solving. People tend to perceive as a unit those things that are close together. Problem solving involves mentally combining and recombining the various elements of a problem until a structure that solves the problem is achieved. Education has the task of developing students cognition. Piaget's (Jean Piaget, 1980) theory of cognition deals with cognitive development from infancy to adulthood. In brief cognitivism implies that mental events are central to human learning which involves the formation of mental associations. Teachers can facilitate students' learning by presenting information in an organized manner.

- Behaviorism: It measures observable behaviors produced by a learner's response to stimuli, which can be reinforced with positive or negative feedback to condition desired behaviors. Thus, learning is but nothing more than the acquisition of new behavior. In the words of B.F. Skinner (1990): Education is what survives when what has been learned has been forgotten'

\section{Educational Systems in Pakistan} follows:

Basically there are two systems of education: 1) Islamic, and 2) English (Western). A brief discussion

\section{a. Islamic system of education}

The Islamic system of education has its origin in the Suffah educational institution set up by the holy Prophet in Madinah, soon after Hijrah in 622 AD. Suffah was essentially a residential university and had a large number of alumni. The course contents included besides the teaching of the Qur'ān, the reading and writing skills [34].

That knowledge in Islam is limited to the Islamic teaching is not correct: rather knowledge is allembracive, both religious and secular aspects as is borne out by many incidents during the holy Prophet's life. The Qur'ān, as emphasized by Hamidullah, itself embraces many branches of knowledge, including physical sciences, besides the matters of faith and morality. The holy Prophet asked Zaid bin Thābit to learn the Hebrews' language (Ibrāni), and he knew four or five language.

Islam, thus, encouraged the setting up of educational institutions and learning of foreign languages. A formal university of al-Karaoune in Morocco, the first in the world extant universities, came up as early as 245/859, followed in 364/975 al-Azhar in Cairo, Egypt. However, it was Nizämiyah Madrassah founded in 459/1067 by the Seljuk Vazir Nizamul Mulk Hassan bin al-Tusi, a friend of Omer Khayyām, which has served as a model educational institution in Islam, till today with minor adjustments. Nizämiyah Madrassah embraced both religious and temporal knowledge, on the faculty of which al-Ghazāli also served as teacher. The curriculum of this Nizāmiyah Madrassah was later on reformed by Mulla Nizāmud Din Sahālwi (1161/1748), known popularly as Dars-e-Nizāmi, which constitutes the standard norm for the main stream of religious education in Indo-Pak sub-continental [35].

It may be of interest to add that knowledge flourished, especially during the Mughal period, reaching its epitome during the Akbar's period (1556-1605) - Akbar known as 'the mightiest sovereigns known to history', maintained a comprehensive library. During his reign a lot of Persian literature in the fields of history, translations and poetry was produced. His successors Jahangir (1606-1627) and Shah Jahan (1628-1666) were great lovers of art and literature. Magnificent works of architecture such as Tãj, the Pearl Masque of Agra the Diwān-i- 'Am, the Diwān-i-Khās, the Jämi' Masjid, the celebrated Peacock Throne, Red Fort and Shalimar Gardens are well known. Tüzuk (Memoirs) of Jahangir is a brilliant proof of his literary attainments. Especially the ladies of the royal household were distinguished by their literary contributions, such as Gulbadan Begam (Babur's daughter) authored Hamāyūnāmah. Zeb-un-Nisā was an expert in calligraphy and had a rich library [36].

Mughal Emperors patronized Madrassah education: Jahangir is known to have repaired Madrassahs while Shah Jahan founded a college at Delhi named Dār-ul-Baqā. Even female education of some sort existed during the Mughal period. However, it appears there was no formal system of schools (Madrassahs) in the country. The death of Aurangzeb on the $3^{\text {rd }}$ March, 1707 signaled the disintegration the mighty Mughal Empire.

Three foreign powers, the Portugese, the French and the British were trying to have their hold in India, of which the British eventually succeeded through obtaining trading rights from the Mughal emperor under the name of East India Company. With the defeat in the battle of Plassy in 1757, Bengal came under the British rule, and in 1857 during the famous battle for Freedom to drive the British out of India, the last Mughal emperor Bahadur Shah Zafar lost the Indian empire, and the British rule established for almost 100 years till 1947 when Pakistan gain freedom.

Some Islamic educational institutions set up in Indo-Pak sub-continent included Nadwah-tul- 'Ulmah founded in 1854, Deuband in 1857 and Jami' Miliyya Islamiya Delhi in 1920 [37]. Of these Deuband was more or less on the lines of Dars-e-Nizāmi. There have flourished a large number of Madrassahs in Indo-Pak 
subcontinent imparting studies of Dars-e-Nizämi, particularly in Pakistan. However, this institution has lately come under fire for militancy and extremism. The Government is in process of registering and reforming the Madrassah stream of education in order to make them compatible with the needs of the time.

\section{b. The English system of education}

It has its roots in Lord Macaulay's Minutes of February 1835 [38]. It gave rise to the establishment in 1857 of universities of Calcutta, Bombay and Madras on the pattern of London university, Muhammad AngloOriented College also founded in 1875 by Sir Sayyed Ahmad Khan at Aligarh, and later Punjab University in 1882, Aitcheson College, Lahore, in 1886. Islamia College Peshawar came up soon later in 1913.

Aligarh Movement launched by Sir Syed Ahmed Khan (1817-1898) to promote English education and the acquisition of science by Indian Muslims played a vital role in the development of Muslim education in India. In fact, 'Shah Wali-Ullah (1703-1762) prepared the ground for Sir Syed's Islamic renaissance of the following $19^{\text {th }}$ century' [39]. Sir Syed founded Muhammadan Anglo Oriental (MAO) college in 1877 [39] However, the first college of Western education was setup by Hindus in 1807 called the Hindu College - He also earlier in 1864 set up Scientific Society. Altaf Hussain Hali was the first Muslim to study English MAO college which was later up graded in 1920 as Aligarh Muslim University and Sir Ross Masood was appointed its first Vice Chancellor. In fact, Sir Syed's initiative was the first milestone of Muslims acquiring modern education in India. Today we owe a heavy debt of gratitude to Sir Syed Ahmed Khan for his foresight in liberating Muslims from ignorance and poverty and putting them onto a path of progress through education.

When Pakistan came into being in 1947 we inherited only one university - the University of the Punjab founded by the British in 1882. Soon afterwards university of Sindh Jamshoro was established in 1947, followed by universities of Peshawar and Karachi in 1950 and 1951 respectively. Currently there are 140 universities both in public and private sectors. A very important role has been played by the Higher Education Commission (HEC) established in 2002 for the evaluation, improvement and promotion of higher education in the country, of which Prof. Dr. Atta-ur Rahman gets the credit for being the first Chairman till 2008, during which time he made laudable efforts to promote quality higher education, setting appropriate standards. Nevertheless there are only a few universities (only 3 - NUST: rank 376, University of Karachi and Quaid-e-Azam university: rank 564) which ranked among the 600 top universities of the world in 2007. This shows how poorly we trail behind the advanced world in the field of education. Today it is due to the English system of education which made possible the advancement of Pakistan in the field of education, particularly in the field of science. Unfortunately the Islamic system of education has never seen favourably the English system of education.

\section{c. Madrassah vis-à-vis English (Western) stream of educational system}

The dichotomy among the two systems has been blamed for much educational malaise in Pakistan and there are serious consultations to reform the situation, particularly the Madrassah education. Let alone dichotomy, in fact, there are three conflicting streams of education currently in vogue in Pakistan: The Madrassah education, the secular school system which is further divided into public and private sectors - the private sector using Urdu medium of instruction and trailing behind while the private sector is aggressive in imparting quality education through English medium of instruction, though at high cost; the gulf between the two is widening. Some serious policy planning has to be done to streamline the situation.

In the words of Hoodbhoy: 'Clarity of purpose, political will, adequate financial resources for education, and willingness to appreciate and use modern technology - arranged in this order - can transform Pakistan's school system. Should we dare to hope?' [40]

\section{Development of Educational System in England}

Pakistan system of English education is based on the British system of education. Thus, a brief development of the British system is discussed in this section. Formal education in England started about the middle of the $18^{\text {th }}$ century. At that time No town outside London had more than 50,000 populations, except Bristol and possibly Norwich. Sanitation and water-supply were inadequate. The education system was essentially tripartite type; briefly discussed below [41]:

\section{a. Elementary education}

Elementary education was undertaking by private individuals, under the aegis of the Church, in such schools as the 'dame schools', the 'charity schools' and the schools run by industry. The 'Sunday schools' were yet another type for those children employed in local factories. In general the environment of these schools was pathetic. Elementary schools prepared students between the ages of 5 and 13 for entry into Grammar schools on the basis of $11+$ examination. Those who did not qualify went to Secondary Modern School, or to a Technical School. It was the Elementary Education Act of 1870 which laid the foundation of the improvement of education in England. A spirit of experiment and free inquiry was encouraged. This Act made education within 
the reach of the poor for both sexes indiscriminately. Elementary education became effectively free with the passing of 1891 Education Act.

\section{b. Grammar (secondary) schools}

These were the endowed schools (grammar school) and the private schools. Winchester was founded in 1382 and Eton in 1440. Both were boarding schools. Rugby, a rather 'glorified' grammar schools founded in 1567. Likewise schools were setup at Harrow and Shrewsbury. These grammar schools were meant for the children of wealthy parents. They taught Latin and Greek, with arithmetic as extra. The purpose was to impart the pupils mental discipline. The system of education was traditional and harsh - bullying was not uncommon. These schools had to have a license to be granted by the Bishop. However, later on the license was abolished, particularly after the Endowed Schools Act in 1869. The schools were reviewed by a Royal Commission and their curriculum remodeled on the lines of German secondary schools Gymnasium. Grammar Schools provided education for academically gifted students between the ages of 12 and 19. Most of the pupils entered university after this.

\section{c. University education}

University education started in Europe much earlier than England and there were 13 universities in Italy, the first one at Modena set up in 1175. 10 universities in France, the first one set up at Paris in 1150, 7 universities in Germany and 5 universities in Spain, etc. England had only two universities up to the year 1500: Oxford set up in 1167 and Cambridge in 1209; however, there were six in the Muslim world during this period

The Royal institutions were founded in 1800 to diffuse knowledge and facilitate technical inventions. This greatly helped the advancement of science in UK. Up to the $19^{\text {th }}$ century Oxford and Cambridge were the only universities in England. They were a 'preserve for the idle and the rich'. The University of London was founded in 1828 - an undenominational teaching institutions, 'the godless institutions in Gower Street' - with curriculum which embraced languages, mathematics, physics, medicine, history, political economy and moral sciences. It was non-residential and cheap compared to Oxford. It was not until 1920 that Oxford admitted women students to full university status. Cambridge was the last to do it.

In 1902 England had only six universities: Besides Oxford and Cambridge, there were four universities at Durham, London, the federal Victoria University, and Birmingham. Soon afterwards in early years of the $20^{\text {th }}$ century more universities came up, such as:

- Manchester and Liverpool in 1903,

- Leeds in 1904,

- Sheffield in 1905

- Bristol in 1909.

- Reading in 1926,

- Nottingham in 1948,

- Southampton in 1952 ,

- Hull in 1954,

- Exeter in 1955, and

- Leicester in 1957

\section{d. Education liberalized and secularized}

The movement of Enlightenment in the $18^{\text {th }}$ century, of which Locke was an early representative, sought the light of reason. As a result the secular education became the State's concern and religious teaching of the Church. Adam Smith (1723-1790) who had been influenced by the Enlightenment, wrote in 1776 his Wealth of Nations; and T. R. Malthus (1766-1834) his famous Essay on Population in 1798. The French Jean-Jacques Rousseau (1712-1778) and the Swiss Pestalozzi (1746-1827) advocated liberal education for the development of the child's capabilities, to develop him into the whole man - the head, the hand and the heart. Later on Froebel (1782-1852), a German and a disciple of Pestalozzi, started Kindergarten schools - a garden where children's are plants and teachers its gardeners to help them develop naturally.

\section{e. The present system}

The Education Act of 1944, also known as the "Butler Act" (reiterated in the Education Reform Act 1988) was the most important legislation of the $20^{\text {th }}$ century which replaced all previous legislation. Education of the individual in his spiritual, mental and physical developments ultimately to similar community's development is the foundation of education. Currently the old tripartite system has disappeared and replaced by the Comprehensive School system. Pupils between the ages of 5 and 11 attend the primary schools, then go to secondary school levels, which normally means entry into a Comprehensive Schools.

These schools take all pupils regardless of ability. At the age of 16 pupils appear for the General Certificate of Secondary Education (GCSE) exam and two years later for another examination called the General Certificate of Education (GCE - A Level). It, then, makes students entry into the University for earning bachelors and higher degree of education. Almost 87 per cent pupils in England attend Comprehensive; others attend Secondary Modern and Secondary Technical schools. The British system of education has been most 
successful in producing both literary and scientific culture - a system in which merit matters - which has been already surved as a model, despite its drawbacks for many developing countries.

\section{Conclusion}

The Islamic system of education started in 622 AD from Suffaih residential school at Madinah. Overtime educational institutions developed in the Muslim world and by the year $1500 \mathrm{AD}$, there flourished six universities as follows: 1) In $859 \mathrm{AD}$ - Fez (Morocco): University of Al-Karaouine - the oldest degree granting university in the world. 2) In $975 A D$ - Cairo (Egypt): AL-Azhar University. 3) In $1065 A D$ - Baghdad (Iraq): Nizamiyah University (branch in Isfahan). 4) In $1233 A D$ - Baghdad (Iraq): Mustansiriya University established by Abbasid Caliph al-Mustansir, merged into the Baghdad University in 1962. 5) In $1327 A D$ - Timbuktu (Mali): University of Sankore. 6) In $1453 A D$ - Istanbul (Turkey): Istanbul university. Against this there were only two universities set up by the Church in England: one at Oxford in 1167 and the other at Cambridge in $1209 \mathrm{AD}$, and one at Bologna in Italy, setup in the year $1088 \mathrm{AD}$.

While the universities in the Muslim world taught comprehensive curriculum, Oxford and Cambridge universities primarily emphasized the learning of Latin and Greek, with arithmetic as extra. It is worth consideration that after the year $1500 \mathrm{AD}$, with while Europe embarked upon the Age of Enlightenment and Renaissance [42] - The name, 'Renaissance' has come to be applied to the whole time roughly from 1400 to 1650, 'Individualism was another hallmark of the Renaissance' [43] - the education in the Muslim world began to decline. John Locke (1632-1704), with this book on Education published in 1693, is considered as the founder of empiricism. He emphasized the role of reason in education [17]. Today's scientific supremacy of Europe is a matter of the last three centuries i.e. since the $18^{\text {th }}$. During this period, while Europe embarked on secular scientific knowledge, the Muslims disdained and discouraged it. That is where Muslims stalk and stand today. It is through knowledge that the nations win the battle today, rather than in battle-fields.

\section{Acknowledgement}

The research was undertaken under Professor Dr. Zia-ul-Haq, head of Islamic Studies, National University of Modern Languages (NUML), Islamabad - Pakistan, to whom I owe a debt of gratitude for his expert guidance.

\section{References}

[1] Hoodbhoy, Pervez, Islam and Science, London: Zed Books Ltd. 1991.

[2] Uthaimīn, Muhammad Bin Saleh Bin, Kitāb-ul- 'Ilm, Iskandriya: Dar-ul- Īmān, 2002.

[3] Ismail, Mohd Zaidi b., 'The Cosmos as the created book and its implications for the orientation of science', Islam and Science, 6:1, 2008 .

[4] Al-Isfahāni, Al-Rāghib, Mu’jam Mufradāt Alfāž al-Qur'ān, Beirut: Dār al-Kutub al-'Ilmiyyah, 1997.

[5] Rosenthal, Franz, Knowledge Triumphant: The Concept of Knowledge in Medieval Islam, Leiden: E.J. Brill, 1970.

[6] Al-Shūkan̄̄, Muhammad bin Ali bin Muhammad, Fateh-ul-Qadīr, Beirut, Lebanon: Dar-ul-Kitāb al-Arabi, $1422 / 2001$.

[7] El-Nejjar, Z. R. 'Islam and the teaching of science (pure and applied sciences) or cosmic sciences', in Knowledge for What?, Islamabad: National Hijra Council, 1986.

[8] Adler, Mortimer J., (Editor in Chief), The Great Ideas: A Syntopicon of Great Books of the Western World, vol. 2, Chicago: William Benton, Encyclopaedia Britannica Inc., 1987.

[9] Commins, Saxe \& Robert N. Linscott (eds.), Man and the Spirit: The Speculative Philosophers, New York: Modern Pocket Library, 1954.

[10] Qadir, C.A., 'Pre-Islamic Indian Thought' in A History of Muslim Philosophy by M.M. Sharif, vol. 1, Karachi: Royal Book Company, 2007.

[11] Commins, Saxe \& Robert N. Linscott (eds.), Man and Man: The Social Philosophers, New York: Modern Pocket Library, 1954.

[12] Didsbury, Howard F. Jr., 'Pre-Islamic Chinese Thought' in A History of Muslim Philosophy by M.M. Sharif, vol. 1, Karachi: Royal Book Company, 2007.

[13] Bausani, Alessandro, 'Pre-Islamic Iranian Thought' in A History of Muslim Philosophy by M.M. Sharif, vol. 1, Karachi: Royal Book Company, 2007.

[14] Shushtery, A.M.A, Outlines of Islamic Culture, Bangalore: The Bangalore Publishing Company, 1954.

[15] Nasr, S.A and M. Aminrazarvi, An Anthology of Philosophy in Persia, vol. 1, Lahore: Sohail Academy, 2005.

[16] Sharif, M.M., "Greek Thought, The Early Beginnings", A History of Muslim Philosophy, vol. 1, Karachi: Royal Book Company, 2007.

[17] Russell, Bertrand, History of Western Philosophy, London: Routledge Taylor \& Francis Group, 2003.

[18] Rizavi, Sayyid Sajjad, Islamic Philosophy of Education, Lahore: Institute of Islamic Culture, 1986.

[19] Madkour, Ibrahim, 'Al-Fārābī', in A History of Muslim Philosophy by M.M. Sharif, vol. 1, Karachi: Royal Book Company, 2007.

[20] Al-Ma'sumi, Muhammad Saghir Hassan, 'Al-Fārābī', in A History of Muslim Philosophy by M.M. Sharif, vol. 1, Karachi: Royal Book Company, 2007.

[21] Rahman, Fazlur, 'Ibn Sina', in A History of Muslim Philosophy by M.M. Sharif, vol. 1, Karachi: Royal Book Company, 2007.

[22] Binder, Leonard, 'Al-Ghāzzalī’ in A History of Muslim Philosophy by M.M. Sharif, vol. 1, Karachi: Royal Book Company, 2007.

[23] Khalid, Tanvir, Mrs., Education, Islamabad: National Book Foundation, 1995.

[24] Bakar, Osman, Tauhid and Science, Lahore: Sohail Academy, 1998.

[25] Mahdi, Muhsin, 'Ibn Khaldūn' in A History of Muslim Philosophy by M.M. Sharif, vol. 2, Karachi: Royal Book Company, 2007.Tanvir Khalid (Mrs.), pp. 82-87.

[26] Dar, B.A., 'Mahmud Shabistari, al-Jili and Jami' in A History of Muslim Philosophy, by M.M. Sharif, vol. 2, Karachi: Royal Book Company, 2007. 
[27] Nasr, Seyyed Hossein, 'Şadr al-Dīn Shirazi (Mulla Şadra)' in A History of Muslim Philosophy by M.M. Sharif, vol. 2, Karachi: Royal Book Company, 2007.

[28] Iqbal, Muhammad, The Reconstruction of Religious Thought in Islam, Lahore: Institute of Islamic Culture, 1999.

[29] Durant, Will, The History of the Philosophy, London: Oxford University Press, 1956.

[30] Commins, Saxe \& Robert N. Linscott, Man and the Universe, New York: Modern Pocket Library, 1954.

[31] Webb, Clement C. J., A History of Philosophy, London: Oxford Uni Press, 1956.

[32] Commins, Saxe \& Robert N. Linscott (eds.), Man and the State: The Political Philosophers, New York: Modern Pocket Library, 1953.

[33] English, Horace B., Child Psychology, Lahore, University Book Agency, 1952.

[34] Hamidullah, Dr. Muhammad, Khutbāt-e-Bahāwalpur, Urdu,Islamabad: Idārah Tahqiqāt-e-Islāmi, 1990.

[35] Anon, Dīni Madāris ka Nizām-e-Ta'līm, Urdu (Education System of Islamic Madrassahs), Islamabad: Institute of Policy Studies, 1993 .

[36] Majumdar, R. C. H. C. Raychaudhuri and Kalikinkar Datta, An Advnced History of India, New Delhi: Macmillan India Limited, 2006.

[37] Akram, Sheikh M., Mauje Kosar, Rawalpindi: Services Book Club, 2004.

[38] Das, K.K., Development of Education in India, New Delhi: Kalyani Publishers, 2006.

[39] Pasha, Muhammad Abdullah, Sir Syed Ahmed Khan: His life and time, Rawalpindi: Ferozsons Pvt. Ltd. 1998.

[40] Hoodbhoy, Pervez, "Education: signs of hope", The Daily Dawn, $9^{\text {th }}$ February, 2007.

[41] Barnard, H.C., A History of English Education, London: University of London Press, 1963.

[42] Rowen, Herbert H., A History of Early Modern Europe, 1500 - 1815, New York: Holt, Rinehart and Winston, Inc., 1960.

[43] Perry, Marvin, Western Civilization, A Brief History, New York: Houghton Mifflin Company, 1997. 